\title{
A Survey of Postgraduates' State of Language Learning at Graduate School, Chinese Academy of Social Science
}

\author{
Yingjie Wang \\ The School of International Education, Shandong University of Finance and Economics, Jinan, China; \\ The Graduate School of Chinese Academy of Social Sciences, Beijing, China
}

\begin{abstract}
Learning English has become a nationwide endeavor in China nowadays, and a great number of researches have been conducted to analyze the state of language learning mainly among undergraduates. This survey was done to investigate the postgraduates' state of language learning at Graduate School of Chinese Academy of Social Science in order to stand a better position to improve their language learning. The survey shows that postgraduates have strong motivations (intrinsic and extrinsic) to learn English and consequently they make investment (spend time, effort or money) in learning English. The survey also indicates that it seems unnecessary to worry about Chinese language and culture in the context of English fever at Graduate School of Chinese Academy of Social Science since postgraduates have a strong identity with their mother tongue --Chinese and most of them deny that English learning has a negative effect on Chinese learning. Consequently, postgraduate schools should help students to maintain their motivation or even expand their intrinsic motivation to learn English without too much concern about the perception that Chinese will be undermined owing to the "craze" for English learning.
\end{abstract}

Index Terms - language learning, postgraduates, motivation, English, Chinese

\section{INTRODUCTION}

The language of language has gradually attained a "genuinely global status" with a "special role that is recognized in every country" as a national language, official language or priority foreign language (Crystal, 1997, p.2).

Learning English has become a nationwide endeavor pursued at all academic levels in China, which is no exception at the Graduate School of Chinese Academy of Social Science (GSCASS). By contrast, Chinese language, as the mother tongue of most Chinese, seems to be less significant than English and has practically been ignored by universities since there are barely any Chinese courses. The survey was conducted to find out what the state of language learning (e.g. attitude, motivation, need, and identity) is in order to stand a better position to understand and improve the language learning at GSCASS.

\section{LITERATURE REVIEW}

Researchers have long been interested in the attitudes of the learner towards the target language. The study of language attitudes traces back to the work of Gardener and Lambert (1972). According to Gardener (1985), attitude is relevant to a person's values and beliefs in language learning. Gardener defined motivation as the combination of desire and effort made to achieve a goal which is associated with the learner's rationale for learning activity and degree of effort employed in achieving goals. Later Gardner and MacIntyre (1993) redefined motivation as a complex construct, which consists of three main components: "desire to achieve a goal, effort extended in this direction, and satisfaction with the task" (p.2).

Gardner and Lambert (1972) distinguished instrumental motivation, which occurs when a learner has a functional goal, and integrative motivation, which occurs when a learner wishes to identify with the culture of the L2 group.

While Gardner's regarded motivation as a static factor in the process of learning a second/foreign language, Deci and Ryan (1985) regarded motivation as a dynamic concept in the framework of self-determination theory. They distinguished amotivation, extrinsic and intrinsic motivation. Students with amotivaion consider it meaningless at all to learn a foreign language and are reluctant to spend any time on it. Extrinsic motivation is the result of any number of outside factors (e.g., the need to get English certificates). In contrast, intrinsic motivation origins from within the individual, (e.g., the learner's interest in the targeted language).

Peirce (1995) criticized conceptions of motivation raised by Lambert and Gardner $(1972,1985)$. She came up with a dynamic notion --- investment which means if learners invest in a second/foreign language because they believe that they could gain more symbolic and material resources, which would expand the value of their cultural capital. She then argued that this return on investment must correspond with the effort expended on learning the second/foreign language. 
In the past ten years, many researches have been done to identify the motivation of language learning motivation, to explore the relationship between language attitude and language learning. Williams, Burden, and Lanvers (2002) examined the foreign language learners' motivation at the secondary school in the South-west of England. They found that girls' motivation was higher than boys' and that there was a negative correlation between age and motivation. Gan, Humphreys, and Hamp-Lyons (2004) suggested that different levels of success in EFL could attribute to a complicated and dynamic interaction of internal cognition and affect, external stimuli, and social setting. Chen, Warden and Chang (2005) investigated motivation constructs of foreign language learning in a Chinese cultural context in Taiwan. Csizér and Dörnyei (2005) employed structural equation modeling to assess a theoretical model which was concerned with the internal organization of the second language motivation complex and its effect on motivated behavior. Lamb (2007) conducted a longitudinal research into the Indonesian adolescents' attitudes toward learning English at junior high schools over the first twenty months. He revealed that the learners maintained the positive attitudes towards English and prospects of success during the period. Gao, Zhao, Cheng and Zhou (2007) explored the relationship between undergraduates' English learning motivation types and their self-identity changes in China. They found seven types of motivation including going abroad, social responsibility, immediate achievement, learning situation, intrinsic interest, individual development, and information medium. Pratt, Agnello and Santos (2009) found that the career benefit was the strongest motivation for starting to study Spanish, and the score was the strongest motivation for pursuing the study of Spanish in high school in the USA.

In the context of "English fever" in China, some worried that Chinese culture and identity will be eroded. Giles and Johnson (as cited in Gao, Li, \& Bian, 2008) raised Ethnolinguistic Identity Theory and produced a set of criteria which could predict ethnic group's language vitality. According to their criteria, people will maintain their language and identity when they have a very strong identity with his ethnic group and have a weak identity with other groups, and believe that their native language is the important factor in the group.

Some also claimed that the international spread of English marginalizes the status of local languages as well as potentially undermining local culture. To understand of the wide spread of English in the world, Kachru (Bhatt 2001)conceived the idea of three concentric circles of the language The "inner circle" (e.g., UK, USA) represents the traditional bases of English dominated by the mother tongue varieties of the language. In the "outer circle," (e.g., India, Singapore) English has been institutionalized as an additional language. The "expanding circle" (e.g., China, Japan) English is used as the primary foreign language. The inner circle is norm-providing, which means that English language norms are developed in these countries. The outer circle is norm-developing. And the expanding circle (much of the rest of the world) is norm-dependent in that it relies on the standards set by native speakers in the inner circle. Some claim that the international spread of English marginalizes the status of local and regional languages as well as potentially undermining or eroding local culture. Phillipson (2000) offered some valid criticisms of theory and practice in the spread of English and proposed linguistic imperialism which means "the dominance of English is asserted and maintained by the establishment and continuous reconstitution of structural and cultural inequalities between English and other language" (p.46). He then analyzed how English language teaching contributes to the dominance of English worldwide which further erodes the local language and culture. However, Spichtinger (2000) rejected linguistic imperialism and argued that the global spread of English is better understood in the framework of appropriation --English is used around the world for regional purpose. Tarling (2009, p14) suggested the term of "globalization" to replace "imperialism" which "seems to provide a better context for the study of the spread of English, it's challenges and its achievements, and its deficiencies, than imperialism"

In summary, there are not so many researches done where English serves as a foreign language instead of a second language. And Chinese researchers (Wu, Liu, \& Jeffrey, 1993; Wen \& Johnson, 1997; Gao, Cheng, Zhao, \& Zhou, 2003; Ma, 2005; Xu, Peng, \& Wu, 2004; Zhou, Gao, \& Zang, 2011) have mainly focused their research on the undergraduates' foreign language learning motivation and achievement. There is barely any research on Chinese postgraduates' state of language learning.

\section{PRESENTATION OF DATA}

The research was conducted by inviting postgraduates at GSCASS to complete an on-line questionnaire (http://www.sojump.com) (see Appendix B). The questionnaire was mainly concerned with students' state of language learning including language learning attitude, motivation, requirement and language identity.

Seventy one students participated in the questionnaire survey from November 13th to November 27th, among whom $63 \%$ were $\mathrm{PhD}$ candidates while $37 \%$ were Master students.

The overwhelming majority of participants (97\%) considered learning English important (8\%), very important (34\%) or extremely important (55\%) (fig.1). Meanwhile, 90\% participants thought that the classmates around attached importance or much importance to learning English (fig.2). Only 3\% thought that learning English at GSCASS is unimportant (fig.1).

In terms of learning time, $82 \%$ participants spent more than 2 hours per week in learning English except English class leaning and homework, among whom $38 \%$ spent more than 4 hours.

Whereas $70 \%$ participants thought that their English was average or poor, $73 \%$ showed self-confidence in learning English better. A significant number $65 \%$ claimed that they learned English mainly to learn the recent development of 
their field abroad (fig.3). Interestingly, however, only 17\% participants considered what they need to improve urgently is reading academic literature. 59\% considered it necessary to hone their oral English and $48 \%$ claimed they needed to improve academic writing (fig.4).

When it comes to Chinese learning, 75\% participants attached more importance to English than Chinese. However, $62 \%$ participants supported that GSCASS should establish Chinese as a compulsory course (fig.5) although 69\% claimed that their Chinese are good or excellent.

99\% of participants claimed that Chinese language is an integral part of the Chinese nation. And most of them (87\%) would teach Chinese as their babies' first language suppose that they got married with an English language speaker (fig.6).

Only 14\% participants strongly agreed that English learning has a negative influence on Chinese learning. And an even smaller number of participants (13\%) thought that Chinese culture was eroded by western culture in the context of "English fever" (fig.7).

\section{ANALYSIS}

Based on Gardner and MacIntyre's definition of motivation (1993), the majority of postgraduates attached much importance to English learning (fig.1 \& fig.2), and consequently their desire to learn English is fairly strong, and most students had the self-confidence in learning English whose subsets included motivation according to Clement, Gardner, and Smythe (as cited in Peirce, 1995); nearly half of them spent a quarter of total learning time or even more in learning English and almost the same number of students enrolled up for an English training program and made an investment in improving their English, which could be regarded as learners' investment produced by Pierce (1995). Only a few students had amotivation defined by Deci and Ryan (1985) and they thought it was unimportant to learn English and practically the same proportion of students were reluctant to spend time in learning English.

Participants' motivation of learning English (fig.3) mainly originated from their individual, i.e. intrinsic motivation, for example, two fifths students learned English out of their interest and more than three fifth students with the motivation of catching up with the pioneering research abroad. A fair number of students also had the extrinsic motivation, for instance, the requirement of diploma and need for hunting a job, which could be classified as instrumental motivation produced by Gardner and Lambert (1972). A small number of students learned English in order to emigrate, which could be nearly regarded as the integrative motivation. It seems that Gardner and Lambert's distinction of motivation could not apply to Chinese students probably for a dearth of a second language ethnic group and setting in China.

In terms of language learning need, what postgraduates needed most to improve in learning English is speaking instead of academic reading skill, which do not match their leading motivation (to learn the pioneering research abroad) in that postgraduates might have equipped themselves with some academic reading skills over university education period, and also because China is lacking in authentic English communication environment.

Whereas most students attached more importance to English than Chinese and they claimed their Chinese were much better, they still insisted that GSCASS establish Chinese as a compulsory, which demonstrated students had a strong identity with their mother tongue.

The overwhelming majority of students believed that Chinese language is an integral feature of Chinese people. And most students showed strong loyalty to and identity with mother tongue since they preferred Chinese to be taught as their babies' first language if they got married with English native speakers. Hence, based on Giles and Johnson's work (as cited in Gao, Li, \& Bian, 2008), we could predict our mother tongue's vitality. Most students did not believe that English learning has a negative influence on Chinese learning and the western culture is undermining the Chinese culture and language, which proved, from another perspective, students' confidence in mother tongue's vitality. Apparently, English dominance or empiricism could not apply to Chinese universities. For one thing, Chinese still maintain its vitality. For another, English is better understood in the framework of appropriation (Spichtinger, 2000) --English is used merely for regional purpose, or to be specific, in the case of postgraduates, learning English is aimed to catch up with the pioneering research abroad as mentioned above.

\section{CONCLUSION}

This survey analyzed the postgraduates' state of language learning at GSCASS. It has been found that generally, postgraduates have a strong motivation to learn English since most of them consider English learning important or crucial and have confidence in learning English better; there are mainly two types of motivation among postgraduates: intrinsic and extrinsic motivations and the latter has a lot in common with instrumental motivations. Because of postgraduates' strong motivation in learning English, they invest much in it.

It seems unnecessary to worry about Chinese language in the context of "English fever" because a majority of postgraduates have a strong identity with Chinese and most of them deny that English learning has a negative effect on Chinese learning and that western culture is eroding Chinese counterpart. 
According to the survey, GSCASS could help students to maintain their motivation or even expand their intrinsic motivation to learn English without too much concern about the idea that Chinese will be undermined owing to English learning "craze".

Clearly, our survey was limited to a relatively small sample by time constraints, and a fuller research might modify our findings in various ways. And further researches could be done to analyze the relationship between postgraduates' language learning motivation and their achievements.

\section{APPENDIX A. FIGURES}

In your opinion, learning English is

\begin{tabular}{|l|l|l|l|}
\hline choices & n. & proportion \\
\hline unimportant & 2 & & \\
\hline less important & 0 & & \\
\hline important & 6 & & \\
\hline very important & 24 & \\
\hline extremely important & $39.45 \%$ \\
\hline The number of participants & $\mathbf{7 1}$ & & \\
\hline
\end{tabular}

Figure 1 Self-reported attitude towards English learning.

Students around you attach to English learning.

\begin{tabular}{|l|l|l|}
\hline choices & n. & proportion \\
\hline no importance & 2 & \\
\hline little importance & 5 & \\
\hline importance & 54 & \\
\hline much importance & 10 & \\
\hline the number of participants & $\mathbf{7 1}$ & \\
\hline
\end{tabular}

Figure 2 Other students' attitude towards English learning from observation.

You learn English in order to . You could choose more than one answer.

\begin{tabular}{|l|l|l|}
\hline choices & n. & proportion \\
\hline out of interest & 29 & \\
\hline to meet the requirement of degree & 29 & \\
\hline to earn the certificate of English test & 6 & \\
\hline to further the study abroad & 13 & \\
\hline to learn the recent development of your field abroad & $46.85 \%$ \\
\hline to emigrate & 2 & \\
\hline to travel abroad & 3 & \\
\hline to hunt for a better job & $18.31 \%$ \\
\hline others & 4 & $2.82 \%$ \\
\hline The number of participants & $\mathbf{7 1}$ & \\
\hline
\end{tabular}

Figure 3 Motivations to learn English.

What do you think you need to improve most? (You could choose more than one answer.) 


\begin{tabular}{|l|c|c|}
\hline \multicolumn{1}{|c|}{ choices } & n. & proportion \\
\hline listening & 33 & \\
\hline speaking & 42 & \\
\hline academic reading & 12 & \\
\hline academic writing & 34 & \\
\hline translation & $59.15 \%$ \\
\hline cultual and social background & 6 & \\
\hline the number of participants & $\mathbf{7 1}$ & \\
\hline
\end{tabular}

Figure 4 English learning need.

Suppose GSCASS establishes Chinese as a compulsory course. You of it.

\begin{tabular}{|l|l|l|}
\hline choices & n. & proportion \\
\hline strongly agree & 20 & \\
\hline agree & 24 & \\
\hline disagree & 22 & \\
\hline strongly disgree & 5 & \\
\hline the number of participants & $\mathbf{7 1}$ & \\
\hline
\end{tabular}

Figure 5 Attitude towards the establishment of Chinese as a compulsory.

If you got married with an English native speaker, what language would you give priority to while teaching your baby to speak?

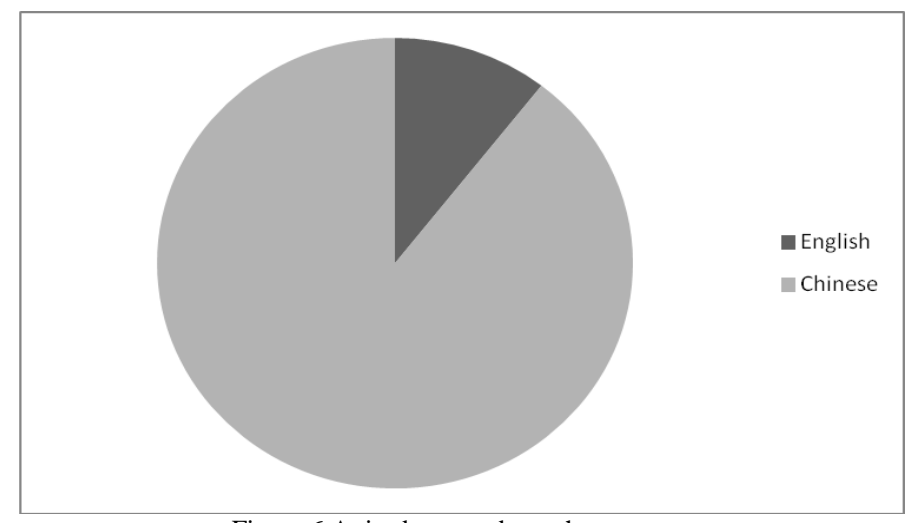

Figure 6 Attitude towards mother tongue.

\begin{tabular}{|l|l|l|}
\hline choices & n. & proportion \\
\hline strongly agree & 9 & \\
\hline agree & 22 & \\
\hline disagree & 30 & \\
\hline strongly disagree & 10 & \\
\hline the number of participants & $\mathbf{7 1}$ & \\
\hline
\end{tabular}

Figure 7 Attitude towards the idea that western culture is eroding Chinese culture.

"Owing to English fever, western culture is eroding Chinese culture." You with it.

APPENDIX B. QUESTIONNAIRE

Tick one box $\square$ if there is no specific emphasis.

1. Your gender: $\square$ male $\square$ female

2. Your age:

$\square 15-20 \square 21-25 \square 26-30 \square 31-35 \square 36-40 \square 41-50$

3. Your major is 
$\square$ History $\square$ literature $\square$ Management $\square$ Economics $\square$ Law $\square$ Philosophy $\square$ Others

4. You are pursuing:

$\square$ Master's degree $\square$ Doctorate degree

5. You are:

$\square$ a first-year student $\square$ a second-year student $\square$ a third-year student

6. In your opinion, learning English is

口unimportant aless important aimportant

口very important aextremely important

7. Your classmates around attach ___ to English learning.

口no importance $\square$ little importance aimportance $\square$ much importance

8. Except for learning time in class, you spend in learning English every week. anever aless than 2 hours $\square 2$ hour to 3 hours

$\square 4$ hours to 6 hours $\quad$ amore than 6 hours

9. Except for learning time in class, the time in learning English accounts for about aLess than $1 / 5 \quad \square 1 / 5 \quad \square 1 / 4 \quad \square 1 / 3 \quad \square 1 / 2 \quad \square 3 / 4 \quad$ amore than $3 / 4$

10. You have in learning English.

口much confidence $\square$ confidence $\square$ little confidence $\square$ no confidence

11. You learn English___(You could choose more than one answer.)

$\square$ out of interest

$\square$ to meet the requirement of degree

$\square$ to earn the certificate of English test

$\square$ to further the study abroad

$\square$ to learn the recent development of your field abroad

$\square$ to emigrate

$\square$ to hunt for a better job

$\square$ for other purposes

12. In your opinion, your English is 口excellent good $\square$ fair $\square$ poor

13. You need urgently to improve English (You could choose more than one answer.) 口listening 口speaking 口reading academic literature 口academic writing to Chinese translation $\square$ socio-cultural background knowledge

14. Have you signed up for English training program? $\square$ No, and I am not going to. $\square$ No, but I plan to.

$\square$ Yes, once. $\square$. Yes, more than once.

15. You__ read Chinese literature (e.g. fictions). $\square$ never $\square$ occasionally $\square$ usually $\square$ always

16. In your opinion, your Chinese is

$\square$ Excellent $\square$ Good $\square$ Fair $\square$ Poor $\square$ Very poor

17. What is your classmates' attitude towards English and Chinese learning?

$\square$ They attach more importance to Chinese .

$\square$ They attach more importance to English.

$\square$ They attach almost the same importance to both.

$\square$ They attach almost the same importance to neither.

18. Do you know about HSK?

$\square$ Not at all. $\square$ A little. $\square$ A lot. $\square$ I took it once.

$\square$ I took it more than once.

19. Do you know about IELTS?

$\square$ Not at all. $\square$ A little. $\square$ A lot. $\square \mathrm{I}$ took it once.

$\square$ I took it more than once.

20. Learning English at GSCASS is

$\square$ extremely important $\square$ very important

$\square$ somewhat important $\square$ not very important $\square$ not at all important

21. Suppose GSCASS establishes Chinese as a compulsory course. You $\square$ strongly approve $\square$ approve $\square$ disapprove $\square$ strongly disapprove of total learning time.

Chinese language is an integral part of the Chinese nation.

$\square$ strongly agree $\square$ agree $\square$ neither agree or disagree

$\square$ disagree $\square$ strongly disagree

23. If you got married with an English native speaker, what language would you give priority to while teaching your baby to speak?

$\square$ Chinese $\square$ English 
24. English learning has a negative influence on Chinese learning. You with it. $\square$ strongly agree $\square$ agree $\square$ disagree $\square$ strongly disagree

25. "Owing to English fever, western culture is eroding Chinese culture." You $\square$ strongly agree $\square$ agree $\square$ disagree $\square$ strongly disagree with it.

26. What opinions or suggestions would you give about language learning at GSCASS?

\section{ACKNOWLEDGMENT}

This work was supported in part by the $6^{\text {th }}$ National Foreign Language Education Fund Program from the National Research Center for Foreign Language Education; the title of the program is College English Curriculum Development for the Junior and Senior Students in Financial Colleges, and the program number is ZGWYJYJJ2012A06.

\section{REFERENCES}

[1] Bhatt (2001). World Englishes. Annual Review of Anthropology (Annual Reviews), 30 (1), 527-550.

[2] Chen, J. F., Warden, C. A., \& Chang, T. (2005). Motivators that do not motivate: The case of Chinese EFL learners and the Influence of culture on motivation. TESOL Quarterly, 39(4), 609-633.

[3] Crystal, D. (1997). English as a Global Language. Cambridge: Cambridge University Press.

[4] Csizér, K., \& Dörnyei, Z. (2005). The internal structure of language learning motivation and its relationship with language choice and learning effort. The Modern Language Journal, 89(1), 19-36.

[5] Deci, E. L. \& Ryan, R. M. (1985). Intrinsic Motivation and Self-determination in Human Behavior. New York: Plenum Press.

[6] Gan,Z., Humphreys, G.,\& Hamp-Lyons, L. (2004). Understanding successful and unsuccessful EFL students in Chinese universities. The Modern Language Journal, 88(2), 229-244.

[7] Gao, Y., Li, Y. \& Bian, Y. (2008). From structuralist to constructivist perspectives - A review of language and identity research. Language Teaching and Research, 20(1), 19-26.

[8] Gao,Y., Cheng, Y., Zhao, Y., \& Zhou, Y. (2003). English learning and changes in self-identity-A quantitative investigation on Chinese college undergraduates. Foreign Language Teaching and Research, 35(2), 132-139.

[9] Gao, Y., Zhao, Y., Cheng Y., \& Zhou, Y. (2007). Relationship between English learning motivation types and self-Identity changes among Chinese students. TESOL Quarterly, 41(1), 133-155.

[10] Gardner, R. \& Lambert, M. (1972). Attitudes and Motivation in Second-Language Learning. Rowley, Ma. : Newbury House.

[11] Gardener, R. C. (1985). Social Psychology and Second Language Learning: The Role of Attitudes and Motivations. London: Edward Arnold.

[12] Gardner, R. C. \& MacIntyer, P. D. (1993). A student's contributions to second language learning. Part II: affective variables. Language Teaching, 26(1), 1-11.

[13] Lamb, M. (2007). The impact of school on EFL learning motivation: An Indonesian case study. TESOL Quarterly, 41(4), 757-780.

[14] Ma, G. (2005).The effects of motivation and effort on foreign language achievement. Journal of PLA University of Foreign Languages, 28(4), 37-41.

[15] Peirce, B. N. (1995). Social identity, investment, and language learning. TESOL Quarterly, 29(1), 9-31.

[16] Phillipson, R. (2000). Linguistic Imperialism. Shanghai: Shanghai Foreign Language Education Press.

[17] Pratt, C. Agnello, M. F., \& Santos, S. (2009). Factors that motivate high-school students' decisions to study Spanish. Hispania, 92(4), 800-813.

[18] Spichtinger, D. (2000). The Spread of English and its Appropriation. Vienna: University of Vienna Press.

[19] Tarling, N. (2009). Imperialism and the imperialism of English. In F. Anderson, M. Yingxin \& N. Tarling (Eds.), The English language and the Asian student (pp. 3-15). Shandong: Shandong University Press.

[20] Wen, Q., \& Johnson, R. K. (1997). L2 learner variables and English achievement: A study of tertiary-level English majors in China. Applied Linguistics, 18(1), 27-48.

[21] Williams, M., Burden, R., \& Lanvers, U. (2002). French is the language of love and stuff: Student perceptions of issues related to motivation in learning a foreign language. British Educational Research Journal, 28(4), 503-528.

[22] Wu, Y., Liu, R., \& Jeffrey, P. (1993). Learner factors and language learning achievement: a survey. Foreign Language Teaching and Research, 93(1), 38-48.

[23] Xu, J., Peng, R., \& Wu, W. (2004). A survey of non-English major undergraduates autonomous English learning ability. Foreign Language Teaching and Research, 36(1), 64-68.

[24] Zhou, Y., Gao, Y., \& Zang, Q. (2011). The development of Chinese undergraduates' motivation for English learning in their junior and senior years: Findings from a longitudinal study in five universities. Foreign Language Teaching and Research, $43(2), 251-260$.

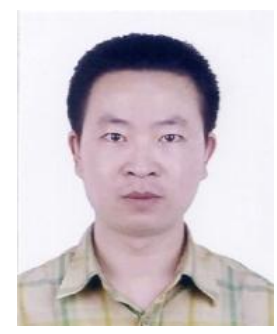

Yingjie Wang was born in Laizhou, Shandong in November, 1978. He is a lecturer in the School of International Education, Shandong University of Finance and Economics. He is also a PhD student at the Graduate School, Chinese Academy of Social Sciences. His fields of specialization are TEFL, linguistics and applied linguistics. 